\title{
8 \\ The Church of the Holy Sepulchre
}

Following the narrow alleys of the Muristan in the Christian Quarter, heading toward Christian Quarter Road, one ultimately faces the Parvis, the enclosed courtyard with its twin portal and main entrance of the Church of the Holy Sepulchre, a rather clustered access often overwhelmed by the relentless movement of visitors (see figure 31). Other than the relative calm on the rooftop compound occupied by the Ethiopian monks, the place is mostly filled with the hustle and bustle of thousands of clergy and pilgrims, creating one of the liveliest scenes in the Old City. ${ }^{1}$ The Church of the Holy Sepulchre represents one of Christendom's holiest sites, venerated as the place of Jesus's crucifixion, burial, and resurrection. Originally built under Constantine the Great in the fourth century C.E., most of the surviving structure is a testimony to the reconstruction programs of the eleventh and twelfth centuries.

The spatial intricacy and complexity of the compound results from the multiple destruction and rebuilding campaigns that have, over centuries, incorporated surviving architectural features into new additions and overall building designs. Housing numerous chapels, niches, and altars shared and administered by six denominations, the church has an atmosphere of spirituality mingled with a mostly manageable chaos, though it frequently gives away to conflicts among the different religious communities. The first attempt to regulate the recurrent frictions was a firman issued by the Sublime Porte in 1767 , establishing a division of the church among the claimants. The territorial partition, as well as the rights and privileges of the communities involved, were reconfirmed by the Status Quo of the Christian Holy Places in 1852. A visual reminder of this partition is the Immovable Ladder (see figure 32), leaning against a window ledge of the church's facade. Except for 


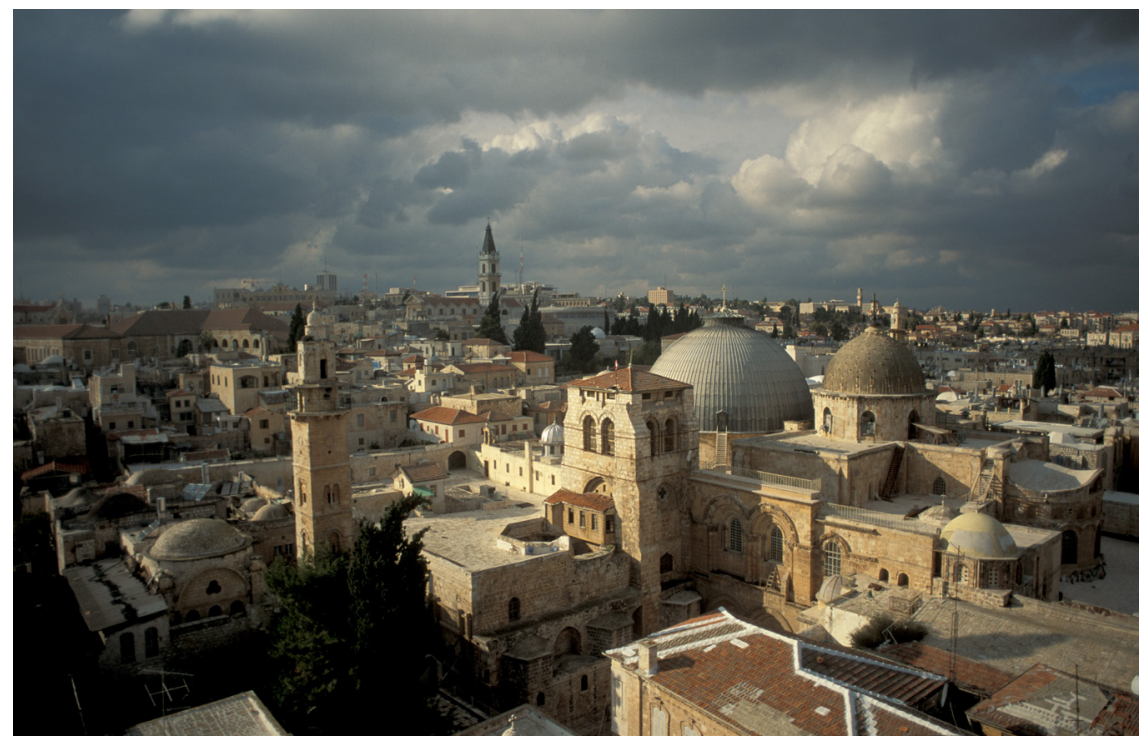

FIGURE 31. Aerial view of the Church of the Holy Sepulchre, looking northwest. Photo by Hanan Isachar.

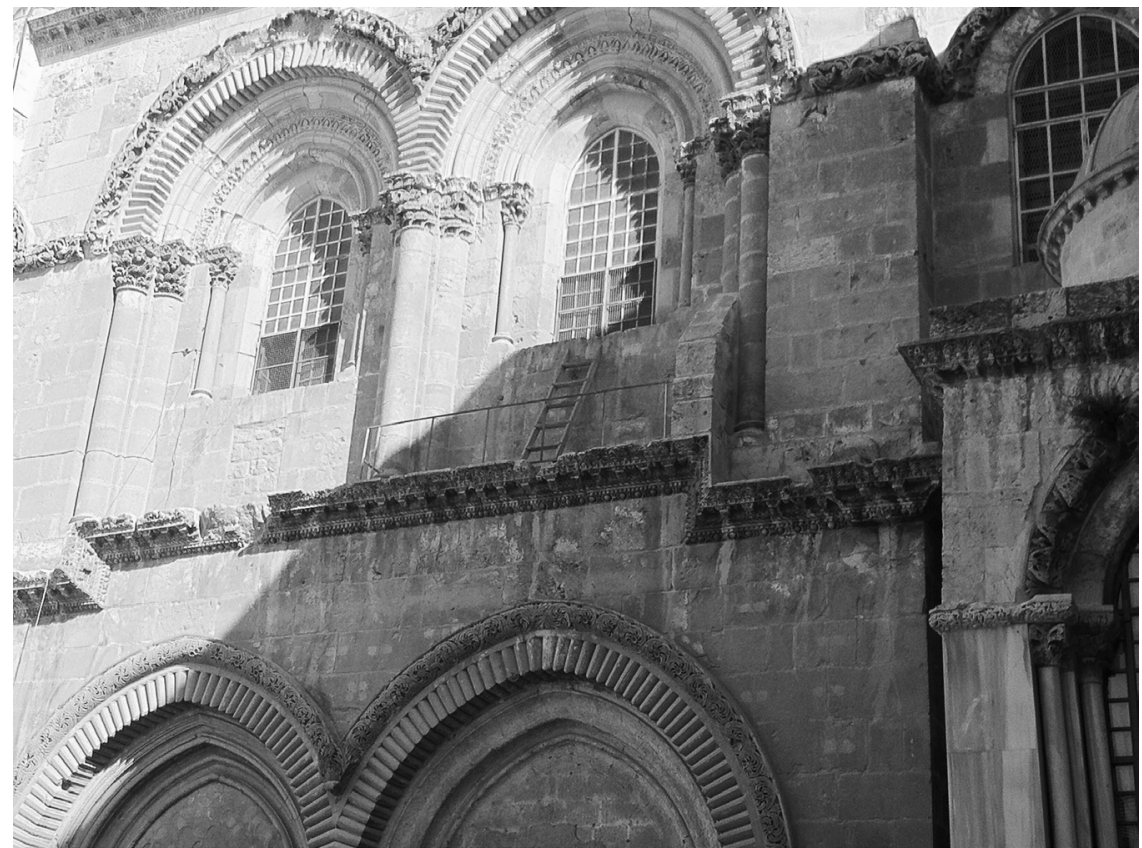

FIgURE 32. The Immovable Ladder of the Church of the Holy Sepulchre. Photo by Katharina Galor. 
two occasions, the wooden ladder has remained in the same location since the eighteenth century, due to an understanding that no community members may move, rearrange, or alter any property without the consent of all six orders. ${ }^{2}$

With the exception of the relatively brief interlude of the Byzantine period, when the church reflected the imperial program of creating a magnet for Christian pilgrims, this monument has existed as an island under Muslim and, most recently, Jewish dominion. A reminder of the long-term Muslim governance of Jerusalem is the fact that the responsibility to open and lock the door of the Holy Sepulchre rests in the hands of Muslims. The keys to the church's main door are held by the Joudeh and Nuseibeh families, allegedly entrusted as custodians by Salah al-Din in the Ayyubid period. ${ }^{3}$

In spite of the sustained tension among the different Christian communities who hold a share in the building, external religious and political pressures have created some kind of unity, a complex situation reflected also in the architectural and archaeological exploration of the site, as well as in its conservation program.

\section{EXPLORATION AND FINDINGS}

Scholarly interest in the Church of the Holy Sepulchre began in the nineteenth century with preliminary studies conducted by George Williams, Melchior de Vogüé, and Charles Wilson, followed by more comprehensive investigations of the history and archaeology of the site by Louis-Hugues Vincent and Félix-Marie Abel at the beginning of the twentieth century. ${ }^{4}$ The severe dilapidation of the church, the result of centuries of neglect, combined with the damage caused by an earthquake in 1927 as well as two fires, one in 1934 and another in 1949, led to the decision to undertake major restoration projects. These initiatives also provided the opportunity for excavations, which were begun in the church complex in 1960. Between 1960 and 1969, Virgilio Corbo, a Franciscan friar working on behalf of his order, explored various areas within the Anastasis, the Chapel of the Apparition to the Virgin, the Franciscan monastery, the gallery over the Virgin's Pillars, and, finally, the Chapel of the Finding of the True Cross. ${ }^{5}$ Additional work was conducted at the invitation of the Greek Orthodox Patriarchate. In 1970 Anastasios Ekonomopoulos supervised the excavation in the area of the Katholikon , and in 1977 Christos Katsimbinis led the work carried out at the Rock of Golgotha. ${ }^{6}$ In 1975 the Armenian Orthodox Patriarchate initiated excavations in the Chapel of St. Vartan, which were originally carried out by untrained clergy of their order and later continued and documented by Israeli archaeologist Magen Broshi. ${ }^{7}$ In 1997, the Coptic Metropolitan of Jerusalem and the Near East invited Israeli archaeologists Gideon Avni and Jon Seligman to work in their section of the church, focusing on the subterranean spaces in between the church and the al-Khanqah al-Salahiyya Mosque and al-Khanqah Street. ${ }^{8}$ 
Excavations conducted underneath the floors of the Church of the Holy Sepulchre and other buildings in its proximity have established that throughout most of the Iron Age, the site was used as a stone quarry. Toward the end of the Iron Age, the area was abandoned and replaced by sporadic domestic construction. ${ }^{9}$ Several late Hellenistic and early Roman burials, cut into the walls of the former quarry, including the so-called Tomb of Joseph of Arimathea, indicate that the area remained outside the city walls until at least through the period associated with the time of Jesus's execution. ${ }^{10}$ Most scholars have interpreted this evidence as support of the description in the Gospel accounts, which concur that Jesus was buried in a newly cut, rock-hewn tomb (John 19:38-41; Luke 23:50-53; Matthew 27:51-61). ${ }^{11}$

According to Eusebius (Vita Constantini 3.26), as part of his newly designed forum, Hadrian built a temple dedicated to Aphrodite on the site of Jesus's burial. The raised podium of the temple was apparently designed to hide the tomb, which left it intact until it was again revealed under Constantine. Late Roman building remains uncovered below the grounds of the church have been associated with the temple and the civic basilica of the city's forum. ${ }^{12}$ When Constantine the Great decided to erect a commemorative church on Jesus's burial site, the first act was to demolish Hadrian's temple. Once the tomb was revealed, the surrounding rock mass was hewn away with the goal of isolating the tomb within a circular plaza. This plaza was then used as a starting point to develop a larger complex known as the Church of the Holy Sepulchre, which originally included four major components (from east to west): the atrium or entrance courtyard, where holy relics were kept; the Martyrium, a large basilica featuring a central nave and four side aisles; the Triportico, an open courtyard incorporating Golgotha, the place mentioned in the Gospels as the site of the crucifixion (Matthew 27:33; Mark 15:22, John 19:17); and finally the Rotunda, also known as the Anastasis (resurrection in Greek) enclosing the Sepulchre or holy tomb (see figure 33 ). ${ }^{13}$ The church incurred damage during the Persian conquest of Jerusalem in 614, and some renovations were made after Emperor Heraclius retook the city in 629.

In 1009 Fatimid Caliph al-Hakim bi-Amr Allah ordered the demolition of the large basilica. From then onward, the Sepulchre and Golgotha became the prime focus of restoration projects, the first major one begun in 1030, under Emperor Constantine IX Monomachus, and the second completed on the fiftieth anniversary of the Crusader conquest in $1149 .{ }^{14}$ The eleventh-century renovation design turned the Rotunda into a circular church with an apse on the east and the main entrance on the south. It was at this point that access to the church was facilitated through the Parvis, still in use as the main entrance into the church to this day. The Crusaders removed the apse and enclosed the Rock of Golgotha, thus incorporating it and the Sepulchre into one coherent structure for the first time, which was built in a typical Romanesque style. ${ }^{15}$ At the same time, a monastery for the Augustinian Order was established on the site of the former Constantinian basilica. The 


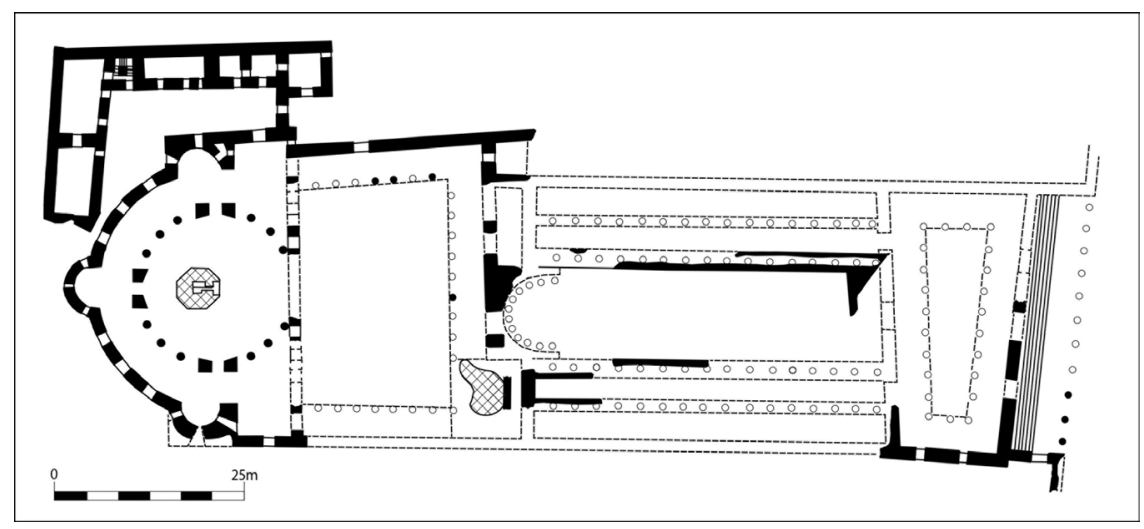

FIGURE 33. Plan of the Constantinian Church of the Holy Sepulchre. Redrawn by Franziska Lehmann, after: Corbo, Il Santo Sepolcro, pl. 3.

present Church of the Holy Sepulchre is primarily a result of these eleventh-and twelfth-century restorations, which incorporated minor traces of the earlier building stages as well as some recent additions and modifications made both within the complex and on the exterior. ${ }^{16}$

During the course of the nineteenth and twentieth centuries, a number of incoherent restoration initiatives were carried out by the different communities responsible of the various subsections of the church. Some of these changes appear to reflect the ethnic origins of the communities in charge. The areas remodeled by the Franciscans, for instance, clearly reflect the architectural and artistic principles of the Western churches, while the sections under the control of the Greek Orthodox order replicate the style of Orthodox churches. ${ }^{17}$ Thus, the architectural history of the Holy Sepulchre reflects the theological and cultural intricacies of the development of Jerusalem's historic churches, their role within the larger Christian world, and finally their relationships with local governance and politics. ${ }^{18}$

\section{BETWEEN FAITH AND SCIENCE}

The desire to validate the site of Jesus's crucifixion and burial and to confirm that the Constantinian church built three centuries later commemorated the authentic location of the events described in the Gospel accounts determined most of the eventual scientific exploration of the Church of the Holy Sepulchre. The resulting scholarship was largely an attempt to understand the physical remains in light of the textual traditions, both the New Testament account and extra-canonical sources. Much of the site's physical development has been explored by members of the church's own communities, but there have also been several recent attempts to 
appoint external and impartial professionals to oversee conservation and restoration initiatives and to conduct and evaluate archaeological excavations. One such initiative was an international conference of architects in 1955 and the creation of a group called the Common Technical Bureau in 1959, bringing together Armenian, Greek, and French architects to oversee surveys and excavation and restoration projects. ${ }^{19}$ The professional and scholarly engagement with the ecclesiastic complex, however, never aroused much interest among the Protestant or Evangelical communities.

In the late nineteenth century, another site was suggested as the place of Jesus's crucifixion and burial. This site, known as the Garden Tomb (see figure 34), is located outside the Old City boundaries, just north of Damascus Gate. Discovered in 1867 , it was first documented by Conrad Schick and other early Jerusalem scholars. $^{20}$ On the occasion of his visit in Jerusalem in 1883, General Charles George Gordon, a British military hero, identified the rock scarp adjacent to the tomb as the hill of Golgotha. Soon after Gordon's visit, his interpretation gained popularity, and a controversy emerged over which site was the legitimate burial place of Jesus. The Church of the Holy Sepulchre was supported mostly by Catholics, the Garden Tomb mainly by Protestants. ${ }^{21}$ Much of the desire to provide an alternative to the traditional site stemmed from the rapidly growing interest of Westerners in visiting the Holy Land and, more specifically, their lack of a proprietary share in the Church of the Holy Sepulchre, as well as their distaste for its gloomy and often filthy spaces, crowded primarily with priests, monks, and pilgrims from Eastern countries. ${ }^{22}$ Most of the literature defending the Garden Tomb as the authentic site of Jesus's burial published since then, however, is based on theological beliefs rather than on scientific arguments. ${ }^{23}$ A renewed archaeological investigation of the tomb initiated in 1974 established that it was hewn and first used during the Iron Age II (eighth to seventh centuries B.C.E.). During the Roman period-that is, when Jesus was crucified and buried-the structure was abandoned and not used again for burial purposes until the Byzantine period. ${ }^{24}$ Other than the Garden Tomb, numerous additional burial structures dating from the Iron Age have been excavated and documented in the area to the north of Damascus Gate, thus supporting a coherent picture for the area in which the Protestant contender of Jesus's burial site is located, both from a functional and a chronological point of view. ${ }^{25}$ The only advantage the Garden Tomb holds over the area of the Church of the Holy Sepulchre is its location beyond the Old City walls; in antiquity, crucifixions and burials would have taken place outside the city boundaries. This advantage, however, does not hold true for the time of Jesus's crucifixion, when the site of the Holy Sepulchre was located outside the Second Wall. The Third Wall, which brought the site into the boundaries of the protected city, was built shortly after Jesus was executed, sometime between 41 and 44, under the reign of Herod Agrippa I, the grandson of Herod the Great. ${ }^{26}$ Hadrian's attempt to obliterate the 




FIGURE 34. Garden Tomb. Photo by Katharina Galor.

memory of Jesus's tomb at the beginning of the second century by erecting a pagan temple on it, at which point the site was no longer outside the city walls, has thus been used as the strongest argument in support of preserving the authentic site of his burial. Given the discovery of several funerary structures dating from the general time period of Jesus's ministry and death, both underneath the Church of the Holy Sepulchre and in the adjacent areas, and the logical conclusion that the site was located outside the city boundaries at the time of the crucifixion, the claim of authenticity of the location of the church as the true burial site of Jesus can not be refuted on archaeological grounds. Thus, despite the lack of an ultimate physical proof, the Holy Sepulchre nevertheless holds an advantage over the site of the Garden Tomb. For the latter, archaeological evidence establishes unequivocally that the area had not been used as a burial ground at the time of Jesus's death.

The history of the Church of the Holy Sepulchre's Aedicule (the little structure enclosing what was believed to represent Jesus's actual burial), located within the heart of the Rotunda, has been far less contentious. Martin Biddle's recent study of the successive shrines that were built over the site of the purported tomb, from the time of Constantine to the present, has maintained its place as the most authoritative voice on the subject. ${ }^{27}$ The present Aedicule was built in 1810 by the Greek Orthodox community but preserves the interior marble cladding from the sixteenth century. ${ }^{28}$

Beyond the controversy over the location of Jesus's burial place, only a few minor points regarding the architectural history of Church of the Holy Sepulchre have been debated among scholars. Of interest among these is the drawing of a 
ship with an inscription located on a wall of St. Krekor's Chapel. According to Magen Broshi, the drawing was executed during the construction of the foundations of the Constantinian basilica and represents the earliest documentation of a Christian pilgrim to the Holy Land. Shimon Gibson and Joan Taylor reject this view and argue instead for a second-century C.E. date. ${ }^{29}$ Furthermore, various interpretations based on Eusebius's description of the Rotunda have been put forward. According to Corbo, the Anastasis was built as a roofed building at the time of Constantine. In Charles Coüasnon's view, there were two stages, both of them dating to the fourth century; during a first phase, the Sepulchre was a simple mausoleum standing in an open courtyard, surrounded by columns; then, during a second stage, the building was covered, enclosing the tomb..$^{30}$ Various other discrepancies regarding the structural and architectural history of the ecclesiastic complex fill the pages of numerous scholarly publications. ${ }^{31}$ These do not, however, affect the denominational conflicts, which persist to this day.

\section{THE COMMUNITIES: COOPERATION AND FRICTION}

Several different communities currently coexist in the Church of the Holy Sepulchre. These include the three major shareholders: the Greek Orthodox, the Latins (Roman Catholics), and the Armenians. The three minor communities are the Copts, the Syrian-Jacobites, and the Ethiopians. The development of the religious rights and allotments in the church reflects the history of Christianity in the city as it evolved over the course of some seven hundred years. The first significant split between the Orthodox and the Monophysite communities (Armenians, Coptics, Syrian-Jacobites, and Ethiopians) occurred in 451, when the Council of Chalcedon declared that Christ had two natures, one divine and the other human. These theological differences soon transpired in spheres that determined religious practice, social and economic opportunities, as well as cultural and artistic preferences.

In spite of the lack of concrete documentation for a regulated coexistence of various denominations worshipping in the Church of the Holy Sepulchre during the Byzantine and early Islamic periods, it is generally assumed that some informal agreements with regard to conducting different services were in place even from the very beginning. ${ }^{32}$ It appears that it was not until 1054, when Michael Cerularius, patriarch of Constantinople, refused to accept the supreme authority of the pope in Rome, that the division between the Eastern (later Greek Orthodox) and the Western (later Roman Catholic or Latin) branches of Christianity were formally recognized. ${ }^{33}$ With the Crusader conquest of the city, in 1099, and the founding of the Latin patriarchate in Jerusalem, the rift between the Latin and Greek Orthodox communities within the context of the Church of the Holy Sepulchre was firmly established. ${ }^{34}$ 
Beginning with Salah al-Din's conquest of Jerusalem, in 1187, the divisions among different communities were exploited by imposing taxes for the rights of possession within the church. Another means of establishing the polarity between the new religious authority and the inferior status of the tolerated Christian communities living within the city and sharing the church was by handing the keys to the Holy Sepulchre to two Muslim families, a tradition that has survived to the present. ${ }^{35}$

The current spatial distribution in the church originated in the thirteenth century, with minor changes introduced between the fourteenth and sixteenth centuries (see figure 35). Additional modifications were made after the Ottoman conquest in 1516 when the Orthodox, Latins, and Armenians increased their possessions, to the detriment of the smaller communities, who no longer could afford the steadily increasing taxes imposed by the new rulers. ${ }^{36}$ In the mid-nineteenth century, the most significant areas within the church were turned into common property, including the Aedicule, the Rotunda, the Stone of Unction, the south transept, the Parvis, and the entrance to the church. The remaining spaces, many of which are used as chapels, remained divided among the different denominations and include the following: the Katholikon, two of the three chapels in the ambulatory, the northern part of Calvary, the Prison of Christ, most rooms surrounding the Rotunda, various buildings bordering the Parvis, the monastery of St. Abraham and the belfry belong to the Greek Orthodox community; the south part of Calvary, the Chapel of Apparition, the Chapel of Mary's Agony, and the Chapel of the Invention of the Cross are owned by the Latins; the Chapel of St. Helena, the Chapel of the Parting of the Raiment, the Chapel of St. John, the Station of the Holy Women, and one of the rooms bordering the Rotunda belong to the Armenians; the Chapel of Nicodemus and the adjacent Tomb of Joseph of Arimathea are under Syrian ownership; the chapel to the west of the Aedicule, the two rooms south of the Chapel of Nicodemus, as well as a building west of the main entrance belong to the Copts; and finally, the Chapel of St. Michael and the Chapel of the Four Beasts to the east of the Parvis, as well as the courtyard of Dair as-Sultan belong to the domain of the Ethiopians. ${ }^{37}$ Various subsections of the church have changed hands repeatedly over the centuries, intricate allocation processes too complex to review here. Indicative of the volatility of ownership is the Calvary, which was reappropriated five times-going back and forth between the Armenians and Georgians-in a period of only thirty years in the 1400 s. $^{38}$

The first official declaration freezing the rights of worship and possession of the religious denominations within the church was issued in 1852 by Sultan Abdul Mejid, in a decree known as the Status Quo. ${ }^{39}$ The following year, the sultan transferred the power of jurisdiction over the Holy Sepulchre and other holy places of worship from Palestine to the Sublime Porte. In 1878, Article LXII of the Treaty of Berlin incorporated the decrees into international law. The Status Quo, frequently but often inappropriately referenced even today, represents a customary set of 


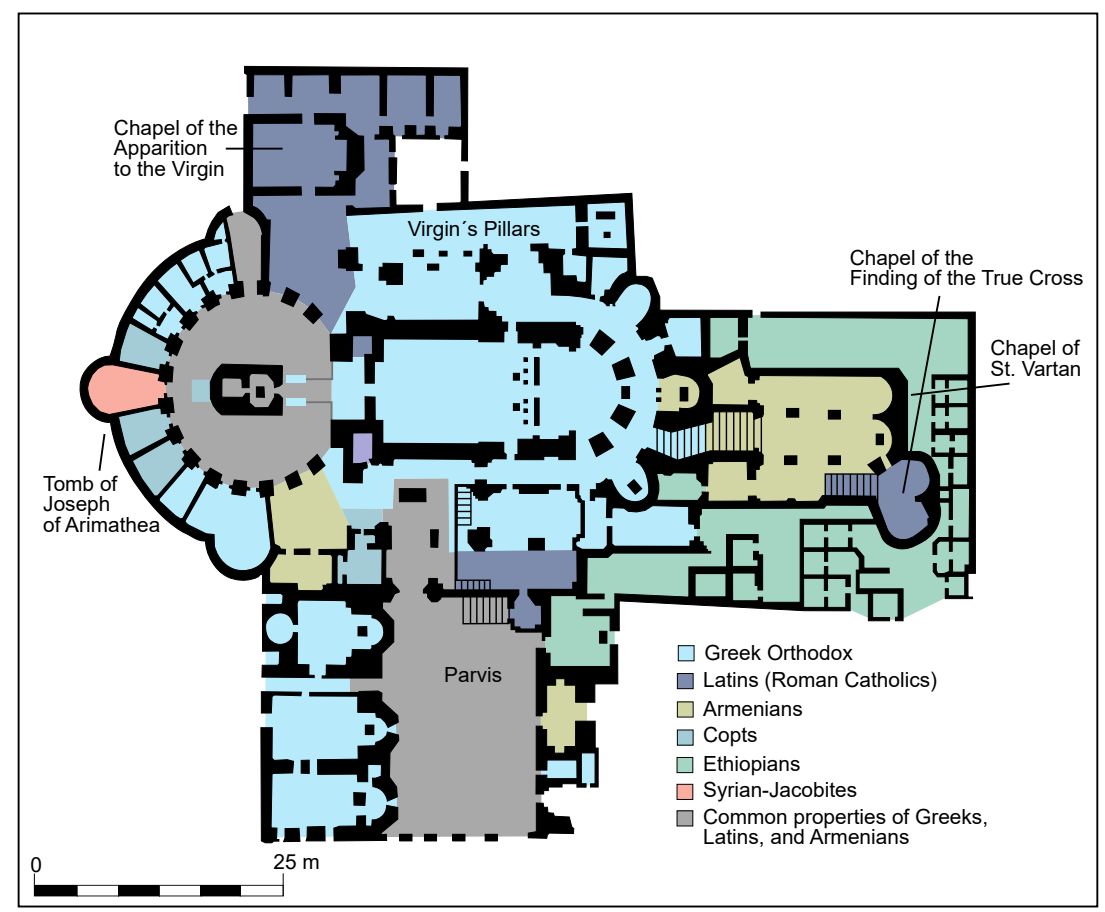

FIGURE 35. Plan showing denominational distribution of space in the Church of the Holy Sepulchre. Drawn by Franziska Lehmann.

practices defining possessions, usage, and liturgy within the church, enabling the different communities to live and worship side by side. Rather than being a definitive code, it consists of a number of overlapping understandings of conventions, with each community holding to its own singular compilation of rules. And it is this flexibility-or rather discrepancy between the different versions-that have maintained the tension and conflicts among the different church orders..$^{40}$

During the first half of Ottoman rule, the more serious conflicts were solved in the Muslim religious courts. After the 1852 firman, most disagreements were handled by the governor. Under British Mandatory administration, efforts were made to both maintain and update the Ottoman system of adjudicating internal church conflicts, a method that itself proved problematic. ${ }^{41}$ Given the lack of official documents codifying established customary rights, it was often difficult, if not impossible, to judge disputes fairly and authoritatively. In an attempt to overcome these difficulties, the administrative complexities increased over time, and authorities of various ranks were consulted, including the district commissioner, the high commissioner, the chief secretary, and sometimes the colonial secretary of state..$^{42}$ In certain ways, the Status Quo of 1852 was maintained even more meticulously during Mandatory rule than during the Ottoman period. Pro forma Israeli policy on the issue of the holy places followed the rules defined by the 
British, which, in the case of the Church of the Holy Sepulchre, became relevant only after Israel's capture of East Jerusalem in 1967. Though Israel acknowledged "its international responsibility for the deep spiritual attachment of other peoples to the Holy City," the government did not assume any legal obligation to honor any of the Status Quo rights. ${ }^{43}$ As a result, any internal conflicts among different religious communities of the Holy Sepulchre brought before the Israeli Supreme Court were relegated to the government, which repeatedly-given the religious and political complexity-refrained from taking decisions. ${ }^{44}$ The tendency under Israeli rule has thus been to defer responsibility and to encourage the communities to resolve conflicts internally.

Disagreements among the various religious communities within the Church of the Holy Sepulchre-the complexity of their internal affairs as well as their tenuous dependencies on the frequently changing legal and governmental policies-have impacted the structural development and maintenance of the building complex. Despite the improvements of the Status Quo system regarding spatial usage and worship regulations, one of its major drawbacks concerns the lack of provision for carrying out repair works. According to Ottoman property law, payment for repair of a structure indicated possession. As a result, whenever one community was willing to cover renovation or construction costs-which would confer to them ownership — the other communities would do their utmost to block the initiative.

Several successful renovations, such as those carried out in the Aedicule in 1555, on the dome in 1719 , or more globally after the fire of 1808 , provided opportunities to lay proprietary claims on certain sections of the church and consolidate existing proprietary rights. At the same time, however, numerous necessary repairs, which transpired over the centuries, were blocked at the outset, a situation that contributed to the substantial architectural dilapidation of the Holy Sepulchre.

In 1933, British architect William Harvey reported the danger of imminent collapse of the Holy Sepulchre and argued that emergency scaffolding had to be erected, a result of centuries of neglect, enhanced by a major earthquake that struck Jerusalem in 1927. Various political events over the next twenty years, including the Arab revolt, World War II, and the 1948 Arab-Israel conflict, delayed immediate action. Among the most absurd proposals was the complete replacement of the entire church complex and half of the Christian Quarter, a solution proposed and endorsed by the Roman Catholic custodianship in 1949, a plan that incorporated a chapel for Anglican use. Fortunately, it was unanimously rejected by both the Greek Orthodox and the Armenian communities. ${ }^{45}$

It was not until 1954 that architects-appointed on behalf of the Greek Orthodox, the Latins, and the Armenians-drew up a joint report documenting the precarious structural condition of the building complex and gave recommendations for feasible solutions. Major restorations were carried out between 1961 and 1980, 
including repair work on foundations, cisterns, walls, ceilings, domes, vaults, columns, and various architectural details.

After the death of the Greek Orthodox Patriarch Benedict of Jerusalem in 1980, the restoration work of the church temporarily came to a halt, and the Common Technical Bureau, originally established in 1952, ceased to operate. The Aedicule, the paving throughout the church, and the electrical and sewage systems were left in a state of disrepair. The 1997 agreement to restore the dome, signed by the three religious communities administering the church in 1994, enabled the scaffolding that had covered the dome since 1970, to be removed. Armenian Patriarch Manoogian referred to the agreement as "a turning point for all Christendom" providing "telling evidence of the new spirit of ecumenical rapprochement" in both the Western and Eastern Christian worlds. ${ }^{46}$ The renovations of the latrine facilities, however, originally agreed upon in 2007 , partially as a result of the improved relations between the Latin and Greek communities, have not yet been implemented. The delay is due to a dispute regarding the sewage line, which runs under the contested grounds of the Coptic patriarchate. The unresolved conflict impacts the Greek Orthodox and Armenian protocols of the miracle of the Holy Fire, an Easter ceremony key to both denominations. ${ }^{47}$ Various other minor gestures and disruptions of established procedures continue to disturb the daily coexistence of the communities, indicative of the denominational rivalry that taints the atmosphere inside the Holy Sepulchre. ${ }^{48}$

\section{BETWEEN RELIGIOUS RIVALRY AND \\ POLITICAL UNITY}

For most of the history of the Church of the Holy Sepulchre, and even during the three centuries that preceded its erection, Christians represented a minority in the city, with limited social and political powers. ${ }^{49}$ Throughout centuries of Muslim and, most recently, Jewish rule, the church persevered as an island of Christian faith, in which different denominations vied for a role in guarding the site for believers from around the world. The building history of the Holy Sepulchre reflects the tumultuous evolution of the Christian presence in Jerusalem and its relationship with the region's ruling powers, which have had varying sympathy toward the church's cause. This history is displayed in the physical signs of multiple destruction and reconstruction programs. ${ }^{50}$ In spite of internal schisms and conflicts between the communities of the church and those conflicts' often negative impact on necessary conservation measures, the architectural and archaeological study of the site has progressed in a relatively coherent direction. One of the primary goals of all involved clergy, professionals, and researchers has been to trace the church's role in preserving the memory of the site of Jesus's burial and crucifixion and how the building complex has adjusted to the ever-changing 
political and cultural context. Other than the objections voiced by the Anglican and Protestant communities with regard to the authenticity of the site, which were based on theological and political rather than on scientific grounds, none of the architectural or archaeological work undertaken in and near the Church of the Holy Sepulchre has threatened the religious and historical validity of the monument in the eyes of the universal church. Indicative of this overall confidence is the fact that, since the 1980s, Israeli archaeologists have been invited by the clergy to contribute to the scientific exploration of the church, serving in some ways as an unbiased professional body, capable of providing an external confirmation of an established tradition.

In contrast to the church's reliance on professional support from Israeli archaeologists, the overall political climate has led to distrust of and opposition to the Israeli government. Since Israel's capture of East Jerusalem in 1967, the clergy of the Holy Sepulchre and, more generally, of the historic churches in the city-which, unlike the local Christian laity, is mostly non-Palestinian-have become more involved politically. Mayor Teddy Kollek's investment in good relations with the Christian communities in the early years after Israel's capture of East Jerusalem started to fall apart in the late 1980s. Since then, various efforts on the part of the Israeli government to discourage the creation of a united Christian front against Israeli policies in Jerusalem and to prevent any possibility of a Muslim-Christian religious coalition, which would strengthen and protect the Palestinian nationalist leadership, have had limited impact. Israel's covert support for settler penetration into the Christian quarters of the Old City has, in fact, led to an unprecedented degree of coordination among the different church denominations. The occupation of St. John's Hospice in April 1990 by a settler movement was a defining event and was indicative of the more recent rapport between the Israeli government and the established Christian communities of Jerusalem. The immediate response of the Church of the Holy Sepulchre was to close its doors to visitors for twenty-four hours, the first time the church had done so in eight hundred years. ${ }^{51} \mathrm{~A}$ more lasting response, indicative of the growing rift between the historic churches and the Israeli government, was the publication of the "Statements by the Heads of Christian Communities In Jerusalem" between 1988 and 1992..$^{52}$ The document implied that the Christian religious leadership would likely have more influence in a bicommunal Palestinian state than in an exclusivist Zionist one in which settlers are given free rein. In this regard, the 1994 Memorandum (another declaration written by the heads of the Christian communities in Jerusalem), a vital document on the significance of Jerusalem for Christians, is the ultimate reference point for any discussion of the Christian role in the city. ${ }^{53}$ It reaffirms the importance of the Status Quo arrangements in their present form..$^{54}$

In spite of the numerous impairments and destructions that the Church of the Holy Sepulchre has suffered, this monument has survived for more than 1,60o years. 
The communities in charge of its upkeep and maintenance have faced numerous internal conflicts, accentuated by the struggles that Christianity has faced more globally. It appears that there are two factors that have allowed the communities and, as a result, the building to survive: first, the need to overcome internal differences and disputes so as to face the threat of external political and religious powers as a united force; and second, the continuity of tradition, which venerates the site and associated building complex as the authentic burial place of Jesus. Unlike numerous, or even most, other Christian holy sites, architectural surveys and archaeological work conducted in and near the Holy Sepulchre have provided additional validation for a centuries-old religious conviction regarding the location of the burial of Jesus. 